\title{
Ignorance is Lack of True Belief: A Rejoinder to Le Morvan
}

\author{
Rik Peels
}

Received: 18 December 2010 / Accepted: 21 December 2010 /

Published online: 16 February 2011

(C) The Author(s) 2011. This article is published with open access at Springerlink.com

\begin{abstract}
In this paper, I respond to Pierre Le Morvan's critique of my thesis that ignorance is lack of true belief rather than absence of knowledge. I argue that the distinction between dispositional and non-dispositional accounts of belief, as I made it in a previous paper, is correct as it stands. Also, I criticize the viability and the importance of Le Morvan's distinction between propositional and factive ignorance. Finally, I provide two arguments in favor of the thesis that ignorance is lack of true belief rather than absence of knowledge.
\end{abstract}

Keywords Latent belief - Dispositional belief $\cdot$ Propositional ignorance $\cdot$ Factive ignorance $\cdot$ True belief $\cdot$ Knowledge $\cdot$ Excuse

\section{Introduction}

In "On Ignorance: A Reply to Peels," (see this issue, pp. 335-344) Pierre Le Morvan gives an interesting and challenging critique of the account of ignorance that I defend in a previous paper in this journal. ${ }^{1}$ In that article, I argue against the thesis that ignorance is lack of knowledge, a view that Le Morvan rightly dubs the Standard View. (p. 335) I took my critique of the Standard View to count in favor of the thesis that ignorance is lack of true belief, a position that I will call the New View. Le Morvan has convinced me that my account needs revision on a couple of points, but I will argue that his animadversions do not seriously threaten the main theses I sought to defend. Also, I elaborate on my argument for the New View which Le Morvan criticizes. Finally, since this argument heavily relies on linguistic

\footnotetext{
${ }^{1}$ See Peels 2010 and Le Morvan 2011. Page references will be to these two articles, unless indicated otherwise.

R. Peels $(\bowtie)$

Department of Philosophy, Utrecht University, Heidelberglaan 8, 3584 CS Utrecht, The Netherlands e-mail: rik.peels@phil.uu.nl
} 
intuitions, I add another consideration to it that favors the New View over the Standard View.

\section{Dispositional and Non-Dispositional Accounts of Belief}

In "What Is Ignorance?," I argue that whether one adopts a dispositional or a nondispositional account of belief makes a crucial difference to one's account of ignorance. Le Morvan criticizes this contention by arguing that my statement of dispositional accounts of belief is seriously wanting and that the dispositional view of belief, as I phrase it, has no advocates. Here is how in that paper I initially characterized the dispositional view of belief:

According to Jonathan Cohen's dispositional account of belief, for instance, "belief that $\mathrm{p}$ is a disposition, when one is attending to issues raised, or items referred to, by the proposition that $\mathrm{p}$, normally to feel it true that $\mathrm{p}$ and false that not-p (...)." This means that one need not have considered a proposition in order to believe it. It also means that for any person $\mathrm{S}$ and proposition $\mathrm{p}, \mathrm{S}$ believes, disbelieves, or suspends judgment on $\mathrm{p}$ (assuming that belief and disbelief are mutually exclusive). (pp. 58-9)

And further on in that same paper I said:

On a dispositional account of the doxastic attitudes, according to which one has some doxastic attitude A toward some proposition $\mathrm{p}$ iff one has a disposition to normally have A toward $\mathrm{p}$ upon considering $\mathrm{p}$, this seems true by definition. (p. 62)

The main idea expressed in both of these passages is this: an account of belief is dispositional if it says or implies that a (specific) disposition to believe something is sufficient for believing it and, hence, that one need not have considered a proposition in order to believe it. A non-dispositional view is any view which entails the denial of this claim.

I think some of Le Morvan's criticisms are right on target. On p. 58, I wrongly equate dispositional with latent belief. What I had in mind is that some beliefs are latent: we believe the propositions in question without currently considering them. According to the adherent of the dispositional account of belief, however, latent beliefs come in two varieties. First, there are what we might want to call dormant beliefs: beliefs in some proposition $p$ that one does not presently consider, although one has considered whether $p$ in the past and the last time one considered $p$, one occurrently believed that $p$. Second, there are dispositional beliefs, beliefs that some proposition $p$ is true despite never having considered whether $p$ and not presently considering whether $p$ either. This distinction squares well with the two passages above. The dispositional view, then, differs from the non-dispositional view in affirming that there are not only dormant, but also dispositional beliefs. I think that it is apt to refer to this view as 'dispositional', for this view has it that a mere disposition to believe that $p$ suffices for believing that $p$, so that one need not ever have considered whether $p$ in order to believe that $p$. 
Also, I think Le Morvan correctly notices that it does not follow from a dispositional account of belief that one has some doxastic attitude or other towards each proposition there is. I think he is right about this, since there are many propositions that we are unable to grasp, either because we lack certain relevant concepts or because they are simply too complex for us. Confucius did not have an attitude toward the proposition that Spain won the FIFA world cup in 2010, because he did not have the concepts of Spain and of the FIFA world cup. And Le Morvan's 4 year old son lacks the concepts of vanadium, elements, and atomic numbers, so he cannot hold any beliefs about those things. Still, it will be true on the dispositional view of belief as I have characterized it that for all propositions that one is able to grasp, one has some doxastic attitude or other toward it. For any proposition that one is able to grasp it is true that upon considering it, one will either believe it, disbelieve it, or suspend judgment on it.

Le Morvan objects that we should distinguish between actual and potential beliefs and that conflating the two multiplies beliefs beyond belief. Before responding, let me point out that it was not my intention to defend the dispositional view. Rather, I wanted to show that which account of belief one adopts makes a difference to one's account of ignorance. If, contrary to what many believe, the dispositional view is mistaken, then that does not count against the point I try to make. As to Le Morvan's criticism itself, I think this is indeed a problem for the dispositional view, but, as it seems to me, the problem does not lie where Le Morvan thinks it lies. I think the problem with the dispositional view is that it ascribes belief to some person in certain cases in which that person clearly does not believe the proposition in question, not that it implies that we have an infinite number of beliefs. Some examples may help here. Frege famously believed that for any property $P$, there is a set whose members are all and only those objects that have $P$ (the so-called 'basic law V'). As Russell showed, however, this thesis is false: for the property of being non-self-membered there is no set whose members are all and only those objects that have $P$. Now, it seems reasonable to suppose that, given his impressive logical skills, if Frege had so much as considered the proposition $q$ that the property of being nonself-membered provides a refuting counter-example to this basic law, he would have believed it. But if he had believed that, he would not have accepted basic law V. But he did. Therefore, he did not believe that $q$. I have to admit that I am not sure what Le Morvan's distinction between potential and actual beliefs amounts to, but perhaps there is some sense in which Frege had a potential belief that $q$ (or, perhaps better, the potential to believe that $q$ ), but not an actual belief that $q$. Here is another example. Take the proposition $r$ that I am currently considering a proposition. Clearly, I always have a disposition to believe this proposition: as soon as I consider it, I believe it. But it seems false that I am always believing this proposition. It follows from these examples that a mere disposition to believe that $p$ is not sufficient for believing that $p$. This is an important problem for the dispositional view: any seriously developed dispositional account of belief has to deal with it.

However, the above two examples should be clearly distinguished from another category of examples. It seems simply false to say that average Western adults do not believe or know (and, hence, believe) that they are less than fifty feet tall, that nobody is identical to a book, and that Obama was not born five centuries ago, although these are all propositions that very few people have ever considered. These 
are clearly not occurrent or dormant beliefs, but it seems that we would nonetheless say that people actually believe or know (and, hence, believe) these things. Again, I do not know what precisely the distinction between potential and actual beliefs amounts to, but it seems that people not only have the potential to believe these propositions (they have the potential to believe pretty much any proposition that they can grasp), but actually believe these things, although not occurrently. Of course, natural language might be misleading, but it seems the only starting point we have when it comes to such matters as giving an account of belief, and we should, therefore, take natural language seriously unless we have good reason to think that it is misleading.

As I said, Le Morvan gives us one reason to think that the dispositional view is misleading: it multiplies belief beyond belief. For, it implies that we have an infinite number of beliefs. I agree that it has such an implication. But what is problematic about that? In raising my hand, I can make a gesture, warn someone, perform a bodily movement, move my limbs, make at least one movement, do something, act after some specific time, act after another specific time earlier than that, and so forth. So, in doing one thing I can do many or perhaps infinitely many things. But then why could I not hold an infinite number of beliefs if I have only considered a limited number of propositions? I suppose that would be problematic if beliefs were material entities, but that thesis is highly controversial and Le Morvan has not argued for it. However, even if I am mistaken about this, I would like to repeat that I did not intend to defend the dispositional view. The point was merely that many in fact adopt a view along these lines, although such views widely differ among each other on the details. This becomes clear if one compares the views of such philosophers as Richard Braithwaite, Frank Ramsey, Gilbert Ryle, Jonathan Cohen, and Eric Schwitzgebel, who all provide a dispositional account of belief. ${ }^{2}$

How does one's account of belief make a difference to one's account of ignorance? Well, imagine that there is some proposition $p$ that I have not considered for a week. Last week, upon considering it, it seemed true to me. If I were to consider it now (which I do not), however, it would seem false to me, because yesterday I acquired additional evidence against $p$. On a dispositional view, one will not believe that $p$, for in the case as I described it, one has a disposition occurrently to disbelieve that $p$ upon considering $p$, given the new evidence I have acquired since last considering whether $p$. What about non-dispositional views? I suppose that my contention that non-dispositional accounts will give a different verdict in this case was slightly too strong. Perhaps there is some particular non-dispositional view that will also imply that one disbelieves that $p$ in the case as described above, although I find it hard to see what such a view would be. Most non-dispositional views, such as the view that if the last time one considered whether $p$ it seemed to one that $p$, then one believes that $p$, will give a verdict different from the verdict given by dispositional views in the case as I described it.

I conclude that, although I was mistaken in claiming that the dispositional account of belief entails that we have a doxastic attitude towards all propositions, the distinction between dispositional and non-dispositional accounts is a viable and

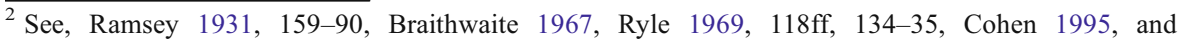
Schwitzgebel 2002.
} 
important one. My claim that dispositional and non-dispositional accounts will result in different analyses of ignorance may not be true for all cases, but it will nonetheless be true for most dispositional and non-dispositional analyses.

\section{Factive and Propositional Ignorance}

According to Le Morvan, I, like most epistemologists, conflate two kinds of ignorance: propositional and factive ignorance. Here is how he explains the notion of propositional ignorance:

Propositional ignorance is ignorance of a proposition, and is incompatible with having any belief that expresses that proposition. For instance, suppose that $\mathrm{p}$ is the proposition that Sam was robbed by a Canadian, and suppose this proposition is false. Sam could not have the belief that $p$ in the first place if he were ignorant of the proposition in question, for one cannot presumably have a belief while being ignorant of its content, the proposition it expresses. (p. 340)

I assume that what Le Morvan has in mind when he says that beliefs express propositions is that beliefs are attitudes towards propositions. If this is right, then, according to Le Morvan, having an attitude towards a proposition entails that one is not ignorant of the content of that proposition, that is, of that proposition itself (for, according to Le Morvan, the content of a proposition is that proposition). I have to admit that I have some trouble in understanding the concept of propositional ignorance. I take it that by $S$ 's being propositionally ignorant of $p$, Le Morvan means that $S$ has not grasped $p$ (not so much that $S$ cannot grasp $p$, but I am not entirely sure about this). Belief, disbelief, and suspension, therefore, entail the absence of propositional ignorance. It also follows that to be ignorant of a proposition is not to be ignorant of its truth, although it entails such ignorance if the proposition is true. To be propositionally ignorant is just to be ignorant of the proposition itself, of 'what it says' so to say (again, I am not sure what this amounts to). Le Morvan adds that if one is propositionally ignorant of $p$, one does not believe, disbelieve, or suspend judgment on $p$. Of course, his non-dispositional account of belief is lurking at the background here. If one were an advocate of the dispositional view of belief, one would endorse that one can have a doxastic attitude toward a proposition even if one has not yet grasped that proposition. Next, here is how, according to Le Morvan, factive ignorance differs from propositional ignorance:

Factive ignorance, by contrast, is ignorance that a proposition is true (if you will: that the state of affairs in virtue of which a proposition is true obtains). To believe that $\mathrm{p}$ implies that one is not propositionally ignorant that $\mathrm{p}$, but it does not follow that one is not factively ignorant that $p$ just because one is not propositionally ignorant that $\mathrm{p}$. For instance, if Sam believes that he was robbed by a Canadian, he is not propositionally ignorant that he was robbed by a Canadian, but it does not follow from this alone that he is not factively ignorant that he was robbed by a Canadian. (p. 340) 
Factive ignorance, then, is ignorance of a proposition's truth value rather than its content. If Sam falsely believes that he was robbed by a Canadian, he is ignorant that he was not robbed by a Canadian, for that is a truth that he fails to know.

Le Morvan considers this distinction to be relevant for two reasons. First, he uses it to attack my argument for the thesis that ignorance is ignorance of truth, that is, that one cannot be ignorant of a false proposition. Le Morvan agrees with me that it is incorrect to describe someone who believes a false proposition $p$ as being ignorant of $p$. That, he claims, however, is not because one cannot be factively ignorant of a falsehood, but because a person who believes a false proposition $p$ is not propositionally ignorant of $p$. If one believes a proposition, one is not propositionally ignorant of it, for believing a proposition entails having grasped that proposition. Le Morvan insists, though, that such a person is factively ignorant. Someone who believes a false proposition is clearly ignorant of something. He concludes that my claim that one can only be ignorant of truth, that is, that one cannot be ignorant of false propositions, is false.

In response, I would first like to point out that the concept of propositional ignorance seems highly unnatural to me. Before today I had never considered the proposition that ducks are smaller than leopards. Is there any natural sense of the word 'ignorance' in which I was ignorant of the content of this proposition? I do not think I was ignorant of the truth of this proposition, but even if I was, is there anything else concerning this proposition, something distinct from the truth of it, that I was ignorant of? I find it hard to think of any such thing. I perfectly understand and have perfectly understood for many years what the sentence expressing this proposition means and what the concepts involved amount to. Even if Le Morvan were to say that one is propositionally ignorant of $p$ if one cannot grasp $p$, the use of the term 'ignorant' seems unnatural to me. If a person cannot grasp $p$, we would not describe that fact by saying that that person is ignorant of $p$-it seems that if we were to say that, we would mean that that person is ignorant of $p$ 's truth. We would rather say that that person is ignorant of the things or concepts involved, that is, of what those things and concepts amount to. Now, one could just stipulate that one is propositionally ignorant of $p$ iff one has never considered $p$. Then, of course, there would be such a thing as propositional ignorance. As we will see, however, we do not need this concept. The concept of factive ignorance suffices to make sense of the relevant cases of ignorance.

Second, I did not say that someone who falsely believes that $p$ is not ignorant simpliciter. What I said is that someone who falsely believes that $p$ is not ignorant of $p$ and by that I mean of p's truth. As it seems to me, when philosophers say that $S$ knows, believes, doubts, or is ignorant that $p$, they always mean that $S$ knows, believes, doubts, or is ignorant that $p$ is true. Now, being ignorant simpliciter and being ignorant of $p$ ( $p$ 's truth) are two different things. Clearly, someone who falsely believes that he was robbed by a Canadian is ignorant of something, namely that he was not robbed by a Canadian. But equally clearly, that person will not be ignorant that he was robbed by a Canadian, because he was not. Here is another example that one might adduce against my claim that all ignorance is factive ignorance. Suppose that Billy spreads all kinds of falsehoods, such as lies and rumors, about Jane. For one thing, he falsely claims that Jane has no friends at all. Jane, however, has no idea that Billy does so. Would we not say that Jane is blissfully ignorant of these 
falsehoods? I think we would (or, at least, we might), but, again, we will have to specify what precisely Jane is ignorant of. It seems that she is ignorant of the fact (the truth) that Billy spreads these rumors and lies about her. But she is not ignorant of the falsehoods themselves. For instance, if she knows that she has many friends, then she is not ignorant that she has no friends at all (remember, this was one of the rumors spread by Billy). As long as we specify which truth we have in mind - which may be a truth that something was not the case - we can explain all ignorance in terms of factive ignorance. Thus, we do not need the concept of propositional ignorance as distinct from factive ignorance in order to make sense of cases in which someone believes a false proposition. I conclude that my claim that one can only be ignorant of truth is undefeated.

Third and finally, Le Morvan complains that one of the premises of my argument against the Traditional View betrays a conflation between propositional and factive ignorance. The premise is that someone who believes a true proposition $p$ without knowing that $p$ is not ignorant of $p$. This, he says, is obviously true for propositional ignorance, for one cannot truly believe that $p$ if one is propositionally ignorant of $p$, that is, if one has not grasped $p$. It does not follow that that person is factively ignorant of $p$. I do not think I conflated propositional and factive ignorance. As I said, I do not believe that there is such a thing as propositional ignorance as distinct from factive ignorance. I was solely concerned with factive ignorance, ignorance of truth. And my contention was that someone who truly believes that $p$ without knowing that $p$ is not ignorant of the fact that $p$ or of $p$ 's truth, although there may be all sorts of other truths in the neighborhood that she is ignorant of, such as the truth concerning the reasons in virtue of which $p$ is true. Below, I will elaborate on this argument against the Standard View.

\section{An Argument for the New View}

Here is how Le Morvan represents my argument in favor of the New View:

$\mathrm{P}_{1}$ : We would not say that someone who believes a true proposition $p$ without knowing that $p$ for some reason or other is ignorant of $p$.

$\mathrm{P}_{2}$ : If I truly but accidentally believe that I will get the job, we would not say that I am ignorant of the fact that I will get the job.

$\mathrm{C}$ : Instances of true belief that fall short of knowledge, albeit instances of some person's lacking knowledge that $p$, are not instances of that person's being ignorant of $p$. (pp. 342-343)

I agree with Le Morvan that if this is how the argument is supposed to run, it is deeply problematic. For one thing, it is not even logically valid, not unless we add a premise to the effect that if in a particular situation we would not say that a person is ignorant, then that person is not ignorant. We should also notice that even if the argument establishes that ignorance is not lack of knowledge, it does not follow that ignorance is lack of true belief. For all I have argued, ignorance may be lack of justified belief, lack of reliable belief, or lack of belief based on good reasons. The only purpose of my argument was to refute the Standard View, not to establish the New View, although I took my argument to suggest that something like the New View is correct. 
I, therefore, propose the following, revised argument against the Standard View and in favor of the New view. The argument has three steps. First, it seems that cases of true belief that are close to knowledge, but somehow just fall short of being cases of knowledge, are not plausible candidates of ignorance (again, I have only factive ignorance in mind). Imagine what I will call case A. I enter my living room and look at the clock. The clock tells me that it is $3 \mathrm{p} . \mathrm{m}$., so that I acquire the belief that it is 3 p.m. I know that the clock has always worked fine, but I have no idea that the clock stopped working 24 hours ago. Would we say that in this Gettier-type case I am ignorant that it is 3 p.m.? It seems implausible to say that I am.

Second, even cases of mere true belief do not seem to count as cases of ignorance. Consider what I will call case B. Jim, a truck driver from Miami, believes contrary to all the evidence that he is going to be the next president of the United States. He thus comes to believe that the next president of the United States currently lives in Miami (let us call this proposition $r$ ). As it turns out, the next president is a female congress member living in Miami whom Jim has never heard of. In this case Jim truly believes, but does not know that $r$. Is he ignorant of $r$ ? It seems to me that he is not. Obviously, there are all sorts of truths in the neighborhood of which he is ignorant and it is hard mentally to isolate $r$ from all those others propositions, propositions such as Mss. Jones is going to be the next president, Mss. Jones lives in Miami, and The next president is currently a congress member. We may be inclined to think that Jim is ignorant of $p$ because we know that he is ignorant of all these other propositions. If we focus on $r$, however, it seems that Jim is not ignorant of $r$.

Third, if both cases of true belief that just fall short of knowledge and cases of mere true belief do not count as cases of ignorance, then it seems plausible that inbetween cases do not count as cases of ignorance either. That is because the constituents of cases that are closer to knowledge than mere true belief but not as close to knowledge as Gettier-type cases entail true belief and are entailed by a Gettier-type belief. It is hard to think of any distinct feature of such cases which would set them apart as cases of ignorance. The above argument can be put slightly more formally as follows:

$\mathrm{P}_{1}{ }^{\prime}$ : In A-type scenarios, $S$ truly believes that $p$, but just falls short of knowing that $p$. [def.]

$\mathrm{P}_{2}{ }^{\prime}$ : In A-type scenarios, $S$ is not ignorant of $p$. [ass.]

$\mathrm{P}_{3}$ : In B-type scenarios, $S$ merely truly believes that $p$ [def.].

$\mathrm{P}_{4}$ : B-type scenarios, $S$ is not ignorant of $p$. [ass.]

$\mathrm{P}_{5}$ : If in both A-type and B-type scenarios, $S$ is not ignorant of $p$, then it is plausible to assume that in all in-between cases - cases in which $S$ truly believes that $p$ without merely truly believing that $p$ and without just falling short of knowing that $p-S$ also fails to be ignorant of $p$. [ass.]

$\mathrm{P}_{6}$ : In all cases in which $S$ truly believes that $p$ without knowing that $p, S$ is not ignorant as to whether $p$. [from $\mathrm{P}_{2}^{\prime}, \mathrm{P}_{4}$, and $\mathrm{P}_{5}$ ]

$\mathrm{P}_{7}$ : If $S$ believes or suspends judgment on a false proposition $p$ or if $S$ fails to believe a true proposition $p$, then $S$ is ignorant as to whether $p$. [ass.]

$\mathrm{C}^{\prime}$ : Ignorance is lack of true belief. [from $\mathrm{P}_{6}$ and $\mathrm{P}_{7}$ ] 
I defined A-type and B-type scenarios as scenarios in which $S$ respectively just falls short of knowing that $p$ and merely truly believes that $p$, which renders $\mathrm{P}_{1}{ }^{\prime}$ and $\mathrm{P}_{3}$ true by definition. I defended $\mathrm{P}_{5}$ above. $\mathrm{P}_{6}$ follows from $\mathrm{P}_{2}^{\prime}, \mathrm{P}_{4}$, and $\mathrm{P}_{5}$, while $\mathrm{C}^{\prime}$ follows from $\mathrm{P}_{6}$ and $\mathrm{P}_{7}$. In the previous paper, $\mathrm{I}$ defended $\mathrm{P}_{7}$, and $\mathrm{P}_{7}$ is even entailed by the Standard View itself. I, therefore, need not defend it here. This leaves us with $\mathrm{P}_{2}{ }^{\prime}$ and $\mathrm{P}_{4}$. Le Morvan complains that $\mathrm{P}_{2}$ begs the question, so I assume he would say the same for $\mathrm{P}_{2}{ }^{\prime}$, or $\mathrm{P}_{4}$, or both of them. ${ }^{3}$ The adherent of the Standard View could indeed simply insist that in B-type scenarios or even in A-type scenarios the cognitive subject in question is ignorant of the relevant proposition. If she not only wants to criticize the New View, but also save the Traditional View, she would in fact have to insist that in both A-type and B-type scenarios the subject is ignorant of the relevant proposition. I have attempted to anticipate this line of response by asking the adherent of the Standard View to consider whether she might conflate ignorance of the relevant proposition with ignorance of propositions that are closely related to it. But if, which I hope not, the adherent of the Standard View, after having considered this response, continues to insist as she did before, then I think we have hit rock bottom: our linguistic intuitions simply divert here. ${ }^{4} \mathrm{I}$, therefore, propose another consideration that may help to convert the adherent of the Traditional View to the New View.

\section{Another Consideration: Ignorance as Excuse}

Another consideration in support of the New View is the following. If the Standard View were correct, true belief that fails to be knowledge would count as ignorance. However, ever since Aristotle it has been widely acknowledged that ignorance, as long as it is blameless, provides at least a partial excuse. ${ }^{5}$ Whereas the New View can make good sense of this, the Standard View cannot. Imagine that, as the director of a destruction company, I decide to destroy an old barn. If I falsely but blamelessly disbelieve that it is an historical monument, I am not blameworthy for destroying the barn. If I have not even considered whether it is and I do not believe that it is and I am blameless for that, then I am not blameworthy for destroying the barn. If I suspend judgment on whether it is, but nevertheless destroy the barn on the basis of the belief that it is unlikely to be an historical monument, then I am blameworthy for destroying the barn, but not as blameworthy as I would have been if I had believed that it was an historical monument. In such a case, then, ignorance provides a partial, although not a full excuse. Since on the New View, every case of ignorance of a proposition $p$ is a case in which one disbelieves that $p$, or in which one suspends judgment on $p$, or in which one has not even considered whether $p$ and does not believe that $p$, the New View can make good sense of the fact that ignorance provides at least a partial excuse.

\footnotetext{
${ }_{3}^{3}$ This is confirmed by his treatment of similar cases in Le Morvan 2010, 312-3.

${ }^{4}$ For the same intuition as I have about cases of true belief that fall short of knowledge, see Goldman and Olsson 2009, 21.

${ }^{5}$ See Aristotle 2003, 123-9, 145-7, 299-305 (NE III.i.13-27; v.7-12; V.viii.3-12). See also Ross 1951, 156-67, Brandt 1969, 349, Smith 1983, 543-71, Fischer and Ravizza 1998, 12-3, Rosen 2003, 61-2, and Zimmerman 2008, 169-205.
} 
On the Traditional View, however, there is another kind of ignorance that differs from the three kinds of ignorance mentioned in the previous paragraph, namely the kind of ignorance that we find in cases in which someone truly believes that $p$ without knowing that $p$. But it seems that true belief that fails to be knowledge does not count as an excuse, not even as a partial excuse. Whether I know or merely truly believe that the old barn is an historical monument does not seem to make a difference to the degree of my blameworthiness. In both cases I am blameworthy to an equally high degree (unless other excuses hold). The Standard View, therefore, entails, contrary to what is widely accepted, that not all kinds of blameless ignorance provide at least a partial excuse. I do not say that the fact that one has this true belief renders one blameworthy to the highest degree possible. It may very well be that someone who also intends to do wrong for wrong's sake is even more blameworthy. If so, however, it will be the absence of such an evil intention rather than the presence of one's belief that partially excuses someone with this kind of true belief.

The Traditional View, therefore, contradicts the thesis that blameless ignorance always provides at least a partial excuse. But since that thesis is widely accepted, this fact provides a good reason to abandon the Traditional View and adopt the New View.

\section{Conclusion}

In this article I have defended the view that ignorance is lack of true belief rather than absence of knowledge. I have argued that the distinction that I made between dispositional and non-dispositional accounts of belief is viable and that one's account of belief makes a difference to one's account of ignorance. Also, I have argued that Le Morvan's distinction between propositional and factive ignorance is untenable. Next, I have provided an argument against the Standard View and in favor of the New View, an argument from linguistic intuitions. Finally, I have added another consideration that favors the New View over The Standard View, a consideration from the widely accepted thesis that blameless ignorance provides at least a partial excuse. ${ }^{6}$

Open Access This article is distributed under the terms of the Creative Commons Attribution Noncommercial License which permits any noncommercial use, distribution, and reproduction in any medium, provided the original author(s) and source are credited.

\section{References}

Aristotle. (2003). The Nicomachean Ethics, transl. H. Rackham. Cambridge, Mass: Harvard University Press.

\footnotetext{
${ }^{6}$ I would like to thank Anthony Booth, Pierre Le Morvan, and Herman Philipse for their helfpul comments on earlier versions of this paper.
} 
Braithwaite, R. B. (1967). The nature of believing. In A. Philips Griffiths (Ed.), Knowledge and belief (pp. 28-40). Oxford: Oxford University Press.

Brandt, R. B. (1969). A utilitarian theory of excuses. The Philosophical Review, 78(3), 337-361.

Cohen, L. J. (1995). An essay on belief and acceptance. Oxford: Clarendon.

Fischer, J. M., \& Ravizza, M. (1998). Responsibility and control: A theory of moral responsibility. Cambridge: Cambridge University Press.

Goldman, A. I., \& Olsson, E. J. (2009). Reliabilism and the value of knowledge. In A. Haddock, A. Millar, \& D. Pritchard (Eds.), Epistemic value (pp. 19-41). Oxford: Oxford University Press.

Le Morvan, Pierre. (2010). Knowledge, ignorance, and true belief. Theoria, 76, 309-318.

Le Morvan, Pierre. (2011). "On ignorance: A reply to peels," Philosophia, 39(2), 335-344.

Peels, R. (2010). What is ignorance? Philosophia, 38, 57-67.

Ramsey, Frank P. (1931). In Richard B. Braithwaite \& George E. Moore (Eds.), The foundations of mathematics. London: Routledge and Kegan Paul.

Rosen, G. (2003). Culpability and ignorance. Proceedings of the Aristotelian Society, 103, 61-84.

Ross, W. D. (1951). Foundations of ethics. Oxford: Clarendon.

Ryle, Gilbert. (1969). The concept of mind (Hutchinson \& Co).

Schwitzgebel, E. (2002). A phenomenal, dispositional account of belief. Noûs, 36(2), 249-275.

Smith, H. (1983). Culpable ignorance. The Philosophical Review, 92(4), 543-571.

Zimmerman, M. J. (2008). Living with uncertainty: The moral significance of ignorance. Cambridge: Cambridge University Press. 